\title{
Quantitative Autoradiography of Multiple 5-HT, Receptor Subtypes in the Brain of Control or 5,7-Dihydroxytryptamine-Treated Rats
}

\author{
D. Vergé,, ${ }^{*}$ G. Daval, ${ }^{*}$ M. Marcinkiewicz,, ${ }^{\star, 1}$ A Patey, $\dagger$ S. El Mestikawy, $\ddagger$ H. Gozlan, $\ddagger$ and M. Hamon $\ddagger$ \\ *Laboratoire de Cytologie, ERA CNRS 884, Université Pierre et Marie Curie, 75005 Paris, †INSERM U. 86, \\ Clinique Ophtalmologique, Hôtel-Dieu, 75004 Paris, and łINSERM U. 288, Neurobiologie Cellulaire et \\ Fonctionnelle, Facultẻ de Médecine Pitié-Salpêtrière, 75643 Paris Cédex 13, France
}

The distribution of the 2 main types ( $A$ and B) of 5-HT 1 binding sites in the rat brain was studied by light-microscopic quantitative autoradiography. The $5-\mathrm{HT}_{1 \mathrm{~A}}$ sites were identified using ${ }^{3} \mathrm{H}-8$-hydroxy-2-( $N$-dipropylamino)tetralin $\left({ }^{3} \mathrm{H}-8-\mathrm{OH}-\mathrm{DPAT}\right)$ or ${ }^{3} \mathrm{H}-5-\mathrm{HT}$ as the ligand. In the latter case, it was shown that ${ }^{3} \mathrm{H}-5-\mathrm{HT}$ binding to $5-\mathrm{HT}_{1 \mathrm{~A}}$ sites corresponded to that displaceable by $0.1 \mu \mathrm{M}$ 8-OH-DPAT or $1 \mu \mathrm{M}$ spiperone. The "non$5-\mathrm{HT}_{1 \mathrm{~A}}$ " sites labeled by ${ }^{3} \mathrm{H}-5-\mathrm{HT}$ in the presence of $0.1 \mu \mathrm{M}$ 8-OH-DPAT corresponded mainly to 5-HT ${ }_{1 \mathrm{~B}}$ sites. 5-HT ${ }_{1 \mathrm{~A}}$ binding was notably high in limbic regions (dentate gyrus, $\mathrm{CA}_{1}$ and $\mathbf{C A}_{3}$ hippocampal regions, lateral septum, frontal cortex), whereas $5-\mathrm{HT}_{1 \mathrm{~B}}$ binding was particularly concentrated in extrapyramidal areas (caudate nucleus, globus pallidus, substantia nigra). Except in the latter regions, where only one class of 5-HT, sites was found, both 5-HT ${ }_{1 \mathrm{~A}}$ and 5-HT $1 \mathrm{~B}$ sites existed in all areas examined. The selective degeneration of serotoninergic neurons produced by an intracerebral injection of 5,7-dihydroxytryptamine was associated only with a significant loss of $5-\mathrm{HT}_{1 \mathrm{~A}}$ binding to the dorsal raphe nucleus $(-60 \%)$ and of $5-\mathrm{HT}_{1 \mathrm{~B}}$ binding to the substantia nigra $(-37 \%)$. These results are discussed in relation to the possible identity of $5-\mathrm{HT}_{1 \mathrm{~A}}$ and/or $5-\mathrm{HT}_{1 \mathrm{~B}}$ sites with the presynaptic 5-HT autoreceptors controlling nerve impulse flow and neurotransmitter release in serotoninergic neurons.

Pharmacological, biochemical and electrophysiological studies have clearly demonstrated the presence of multiple recognition sites for 5-HT in the CNS (Aghajanian, 1981; Hamon et al., 1984a; Nelson et al., 1980; Peroutka and Snyder, 1979). Ligand binding studies first suggested that 2 types of 5 -HT receptors could be discriminated (Peroutka and Snyder, 1979): the 5-HT, class, which exhibits a high affinity for ${ }^{3} \mathrm{H}-5-\mathrm{HT}$ and $5-\mathrm{HT}$ agonists; and the 5- $\mathrm{HT}_{2}$ class which has a higher affinity for ${ }^{3} \mathrm{H}$-spiperone and other 5 - $\mathrm{HT}$ antagonists, notably ${ }^{3} \mathrm{H}$-ketanserin (Leysen et al., 1982).

More recently, evidence has accumulated in support of the heterogeneity of $5-\mathrm{HT}_{1}$ recognition sites. Thus, Pedigo et al. (1981) postulated the existence of 5-HT ${ }_{1 A}$ and $5-\mathrm{HT}_{1 \mathrm{~B}}$ subtypes as a possible explanation of the biphasic displacement by spiperone of ${ }^{3} \mathrm{H}-5$-HT specifically bound to rat cortical membranes. Support for this hypothesis appeared with the discovery that a new 5-HT agonist, 8-hydroxy-2-(di- $N$-propylamino)tetralin

Received Nov. 18, 1985; revised Apr. 21, 1986; accepted May 5, 1986.

This research was supported by grants from INSERM and CNRS (ATP No. 960134).

Correspondence should be addressed to D. Vergé, Laboratoire de Cytologie, ERA CNRS 884, Université Pierre et Marie Curie, 7, Quai Saint-Bernard, 75005 Paris, France.

'Present address: Institut de Recherches Cliniques de Montréal, 110, Ouest, Avenue des Pins, Montréal, Québec, Canada H2W 1RT.

Copyright (C) 1986 Society for Neuroscience $0270-6474 / 86 / 123474-09 \$ 02.00 / 0$
(8-OH-DPAT), is, in fact, a selective ligand of 5-HT $\mathrm{H}_{1 \mathrm{~A}}$ binding sites (Hall et al., 1985; Hamon et al., 1984b; Middlemiss and Fozard, 1983). Subsequent developments in the synthesis of radioactive ligands demonstrated that the situation is probably even more complex, since the use of a new 5-HT antagonist, ${ }^{3} \mathrm{H}$-mesulergine, allowed Pazos et al. (1984b) to characterize a third subtype of $5-\mathrm{HT}_{1}$ binding sites, called $5-\mathrm{HT}_{1 \mathrm{C}}$, that is particularly abundant in the choroid plexus.

Although numerous positive correlations have been observed between the pharmacological profiles of these various $5-\mathrm{HT}_{1}$ binding sites and the pharmacological characteristics of the 5-HT receptors mediating specific behaviors and biological responses (Blackburn et al., 1984; Engel et al., 1983, 1984; Lucki et al., 1984; Middlemiss, 1984; Shenker et al., 1985; Tricklebank et al., 1985), the problem is still far from being solved, and all investigators do not agree about the possible identity of $5-\mathrm{HT}_{1}$ binding sites with true 5-HT receptors (Leysen, 1984).

Since the presence of a given receptor in particular brain areas can be of great informative value [for instance, the presence of opiate receptors within and outside the brain regions involved in the transmission and control of nociceptive messages (see Wamsley et al., 1982), we have studied the detailed distribution of the $5-\mathrm{HT}_{1 \mathrm{~A}}$ and $5-\mathrm{HT}_{1 \mathrm{~B}}$ subtypes in the rat brain, in an attempt to determine whether those binding sites were located, as expected, in the brain regions involved in the various 5-HT-eliciled behaviors and biological responses. For this purpose we used the quantitative autoradiographic technique (Rainbow et al., 1982) applied to brain sections incubated with ${ }^{3} \mathrm{H}-8-\mathrm{OH}-$ DPAT or ${ }^{3} \mathrm{H}-5-\mathrm{HT}$ under conditions ensuring the selective labeling of $5-\mathrm{HT}_{1 \mathrm{~A}}$ or $5-\mathrm{HT}_{1 \mathrm{~B}}$ sites. Furthermore, since data in the literature support that the presynaplic 5-HT autoreceptor controlling 5-HT release from serotoninergic terminals has the same pharmacological properties as the $5-\mathrm{HT}_{1 \mathrm{~B}}$ type (Engel et al., 1983; Middlemiss, 1984), we investigated whether some 5-HT sites (and/or 5- $\mathrm{HT}_{1 \mathrm{~A}}$ sites) disappeared or were at least significantly reduced following selective degeneration of serotoninergic innervation by 5,7 -dihydroxytryptamine $(5,7-\mathrm{HT})$ intracerebral administration.

Materials and methods

\section{Chemicals}

\section{Labeled compounds}

${ }^{3} \mathrm{H}-5$-hydroxytryptamine creatinine sulfate $\left({ }^{3} \mathrm{H}-5-\mathrm{HT}, 12.5-13.8 \mathrm{Ci} /\right.$ $\mathrm{mmol}$ ) was purchased from Amersham International plc (U.K.) and was purified just before use (Hamon et al., 1974). ${ }^{3} \mathrm{H}-8$-hydroxy-2-(di- $N$ propylamino)tetralin $\left({ }^{3} \mathrm{H}-8-\mathrm{OH}-\mathrm{DPAT}, 95-125 \mathrm{Ci} / \mathrm{mmol}\right)$ was supplied by C.E.A. (France).

Other compounds.

5-Hydroxytryptamine creatinine sulfate (5-HT) was from Merck, pargyline from Sigma, fluoxetine from Eli Lilly and Co., lysergic acid di- 
ethylamide (LSD) from Sandoz, guanosine 5'-triphosphate (GTP) from Boehringer-Mannheim, spiperone from Janssen Pharmaceutica, 5,7-dihydroxytryptamine (5,7-HT) from Regis, and reserpine and desmethylimipramine from Ciba-Geigy. Unlabeled 8-OH-DPAT was a gift from Prof. L. Pichat (C.E.A., France).

\section{Animals and treatments}

\section{Reserpine}

Male Wistar rats weighing $250-300 \mathrm{~g}$ were treated with reserpine (10 $\mathrm{mg} / \mathrm{kg}$, i.p.) $24 \mathrm{hr}$ before being sacrificed. Control of the extensive 5HT depletion due to the treatment was made by HPLC coupled to electrochemical detection of the indoleamine high-performance liquid chromatography in the striatum, hippocampus, and cerebral cortex, according to the procedure described in detail elsewhere (Hall et al., 1985).

\section{5, 7-HT lesion}

Animals were anesthetized with chloral hydrate $(400 \mathrm{mg} / \mathrm{kg}$, i.p. $)$ and placed in a stereotaxic frame. Thirty minutes after an i.p. injection of desmethylimipramine ( $25 \mathrm{mg} / \mathrm{kg}$, i.p.), $5,7-\mathrm{HT}(8 \mu \mathrm{g}$ in $4 \mu \mathrm{l}$ of isotonic saline containing $0.1 \%$ ascorbic acid) was slowly infused into the right serotoninergic bundle coming out the anterior raphe nuclei, as described by Nelson et al. (1978). After a $18 \mathrm{~d}$ recovery, rats were used for quantitative autoradiography (see below) or for biochemical control of the lesion: measurements of 5-HT levels (Hall et al., 1985) and tryptophan hydroxylase activity (see Hamon et al., 1981).

\section{Autoradiography}

Rats were anesthetized with chloral hydrate and then sacrificed by an intracardial perfusion with $500 \mathrm{ml}$ of $0.15 \mathrm{~m}$ Sörensen buffer, $\mathrm{pH} 7.4$, before removing the brain from the skull. This perfusion procedure allowed a marked decrease in the nonspecific binding of ${ }^{3} \mathrm{H}-8-\mathrm{OH}-$ DPAT or ${ }^{3} \mathrm{H}-5-\mathrm{HT}$ to brain sections, particularly onto the meninges (not shown). The brains were then frozen at $-30^{\circ} \mathrm{C}$ using isopentane cooled by liquid nitrogen. Coronal sections $(16 \mu \mathrm{m})$ were cut at $-15^{\circ} \mathrm{C}$ in a cryostat, thaw-mounted onto gelatin-coated glass slides, and stored at $-20^{\circ} \mathrm{C}$ until use (within less than 2 weeks).

The sections were labeled in vitro according to the procedure of Rainbow et al. (1982). Tissues were preincubated at $20^{\circ} \mathrm{C}$ for $30 \mathrm{~min}$ in 0.17

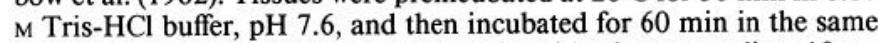
buffer supplemented with $0.01 \%$ ascorbic acid, $10 \mu \mathrm{M}$ pargyline, $10 \mu \mathrm{M}$ fluoxetine, and generally $2 \mathrm{~nm}$ of the appropriate tritiated ligand. Blanks were generated by adding $10 \mu \mathrm{M} 5$-HT to the incubation medium. In experiments designed to characterize the $5-\mathrm{HT}_{1}$ subsites, $0.1 \mu \mathrm{M} 8-\mathrm{OH}$ DPAT, $1 \mu \mathrm{M}$ spiroperidol, or $0.1 \mu \mathrm{M}$ LSD was added to the incubation medium.

After incubation, washing $(2 \times 5 \mathrm{~min}$ in ice-cold buffer and quick dipping in distilled water), and drying with cold air, slices were put in tight contact with a sheet of tritium-sensitive film $\left({ }^{3} \mathrm{H}\right.$-Ultrofilm, LKB, Sweden) and exposed in the dark at $4^{\circ} \mathrm{C}$ for 3 months $\left({ }^{3} \mathrm{H}-5-\mathrm{HT}\right)$ or 2 months $\left({ }^{3} \mathrm{H}-8-\mathrm{OH}-\mathrm{DPAT}\right)$. Alternatively, sections were scraped off the slides and bound tritium was measured by liquid scintillation counting. This procedure has been used notably for the determination of the apparent $K_{\mathrm{d}}$ of ${ }^{3} \mathrm{H}-8-\mathrm{OH}-\mathrm{DPAT}$ binding. In this case, brain sections were incubated with 7 different concentrations of the labeled ligand ranging between 0.20 and $8.5 \mathrm{~nm}$.

Autoradiograms were developed in Kodak Microdol $\left(10 \mathrm{~min}\right.$ at $20^{\circ} \mathrm{C}$ ), and their quantitative analysis was performed with a Quantimet 720 densitometer (Cambridge, U.K.). Results are expressed in optical density (O.D.) units. As already pointed out (Rainbow et al., 1984), the nonlinear response of LKB Ultrofilm to increasing amounts of radioactivity is often a limitation to the use of O.D. measurements. However, in the present case, control experiments carried out with ${ }^{3} \mathrm{H}$-standards showed that, in studies using ${ }^{3} \mathrm{H}-5-\mathrm{HT}$, the measured O.D. was proportional to bound ${ }^{3} \mathrm{H}$ :

$$
\text { O.D. }=0.052 \times B^{*}
$$

where $B^{*}$ is bound ${ }^{3} \mathrm{H}$, expressed in $\mathrm{nCi} / \mathrm{mg}$ protein.

\section{Results}

\section{Characteristics of ${ }^{3} \mathrm{H}-8-\mathrm{OH}-\mathrm{DPAT}$ binding to brain sections}

The direct counting of ${ }^{3} \mathrm{H}-8-\mathrm{OH}-\mathrm{DPAT}$ specifically bound to brain sections at the hippocampal level allowed the determi-
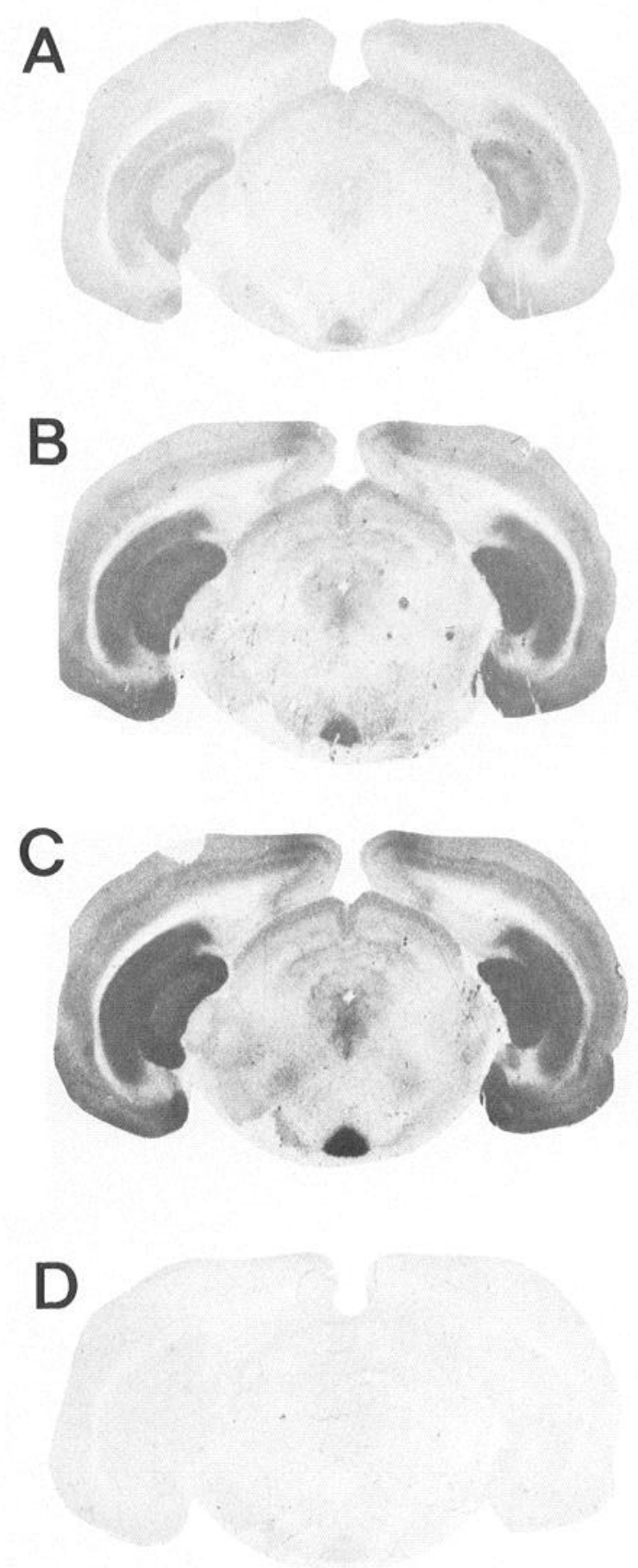

Figure 1. Effects of GTP or $\mathrm{Mn}^{2+}$ on ${ }^{3} \mathrm{H}-8-\mathrm{OH}-\mathrm{DPAT}$ binding to rat brain sections. Coronal sections were taken at $\mathrm{A}=-6.3 \mathrm{~mm}$ from the bregma, according to the stereotaxic atlas of Paxinos and Watson (1982). $A,{ }^{3} \mathrm{H}-8-\mathrm{OH}-\mathrm{DPAT}$ binding in the presence of $0.5 \mathrm{~mm}$ GTP. O.D. measurements indicated an average $72 \%$ reduction compared to autoradiogram $B . B$, Autoradiogram of ${ }^{3} \mathrm{H}-8-\mathrm{OH}-\mathrm{DPAT}$ bound under standard assay conditions (see Materials and Methods). $C,{ }^{3} \mathrm{H}-8-\mathrm{OH}-\mathrm{DPAT}$ binding in the presence of $2 \mathrm{mM} \mathrm{MnCl}_{2}$. Compared to autoradiogram $B$, the mean O.D. increase due to $\mathrm{Mn}^{2+}$ reaches $+27 \%$ in all the structures exhibiting specific ${ }^{3} \mathrm{H}-8-\mathrm{OH}-\mathrm{DPAT}$ binding (hippocampus, dorsal raphe nucleus, interpeduncular nucleus, etc.). $D$, Nonspecific ${ }^{3} \mathrm{H}-8-\mathrm{OH}-$ DPAT binding in the presence of $10 \mu \mathrm{M} 5-\mathrm{HT}$. 

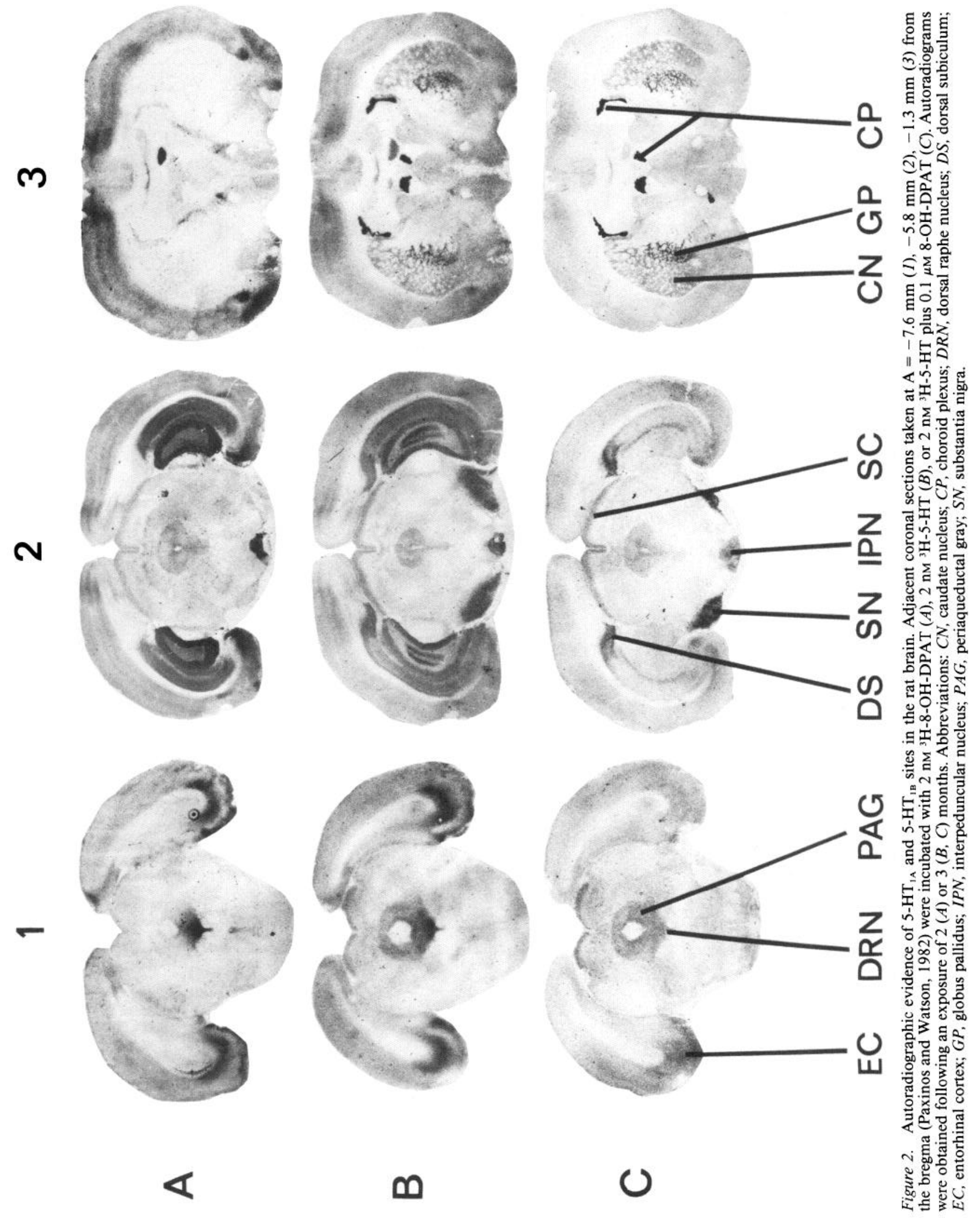
Table 1. Regional distribution of 5-HT ${ }_{1 \mathrm{~A}}$ binding sites in the rat brain

\begin{tabular}{|c|c|c|c|}
\hline \multirow[b]{2}{*}{ Brain structure } & \multicolumn{3}{|c|}{ Specific ${ }^{3} \mathrm{H}$-binding to $5-\mathrm{HT}_{1 \mathrm{~A}}$ sites (O.D.) } \\
\hline & $\begin{array}{l}{ }^{3} \mathrm{H}-8-\mathrm{OH}-\mathrm{DPAT} \\
(5-\mathrm{HT}, 10 \mu \mathrm{M})\end{array}$ & $\begin{array}{l}{ }^{3} \mathrm{H}-5-\mathrm{HT} \\
\text { (8-OH-DPAT, } 0.1 \mu \mathrm{M}) \\
\end{array}$ & $\begin{array}{l}{ }^{3} \mathrm{H}-5-\mathrm{HT} \\
\text { (spiperone, } 1 \mu \mathrm{M} \text { ) }\end{array}$ \\
\hline Dentate gyrus & $0.293 \pm 0.030$ & $0.094 \pm 0.012$ & $0.092 \pm 0.009$ \\
\hline Lateral septum & $0.286 \pm 0.035$ & $0.073 \pm 0.011$ & $0.069 \pm 0.012$ \\
\hline Dorsal raphe nucleus & $0.261 \pm 0.024$ & $0.061 \pm 0.009$ & $0.064 \pm 0.008$ \\
\hline Entorhinal cortex & $0.254 \pm 0.028$ & $0.057 \pm 0.006$ & $0.055 \pm 0.008$ \\
\hline Interpeduncular nucleus & $0.226 \pm 0.016$ & $0.047 \pm 0.004$ & $0.044 \pm 0.007$ \\
\hline Hippocampal $\mathrm{CA}_{1}$ & $0.209 \pm 0.021$ & $0.051 \pm 0.006$ & $0.054 \pm 0.006$ \\
\hline Central amygdala & $0.157 \pm 0.016$ & $0.029 \pm 0.004$ & $0.032 \pm 0.004$ \\
\hline Ventral hypothalamus & $0.130 \pm 0.016$ & $0.026 \pm 0.004$ & $0.034 \pm 0.004$ \\
\hline Dorsal subiculum & $0.126 \pm 0.014$ & $0.013 \pm 0.003$ & $0.014 \pm 0.003$ \\
\hline Frontal cortex & $0.124 \pm 0.014$ & $0.035 \perp 0.005$ & $0.036 \pm 0.005$ \\
\hline Hippocampal $\mathrm{CA}_{3}$ & $0.112 \pm 0.017$ & $0.028 \pm 0.004$ & $0.028 \pm 0.005$ \\
\hline Superior colliculus & $0.076 \pm 0.005$ & $0.015 \pm 0.002$ & $0.020 \pm 0.004$ \\
\hline Stria terminalis & $0.070 \pm 0.009$ & $0.009 \pm 0.003$ & $0.009 \pm 0.002$ \\
\hline Parietal cortex & $0.064 \pm 0.009$ & $0.012 \pm 0.003$ & $0.016 \pm 0.003$ \\
\hline Periaqueductal gray & $0.057 \pm 0.011$ & $0.013 \pm 0.005$ & $0.021 \pm 0.005$ \\
\hline Dorsal hypothalamus & $0.055 \pm 0.014$ & $0.011 \pm 0.003$ & $0.014 \pm 0.003$ \\
\hline Caudate-putamen & nd & nd & nd \\
\hline Globus pallidus & nd & nd & nd \\
\hline Substantia nigra & nd & nd & nd \\
\hline Choroid plexus & nd & nd & nd \\
\hline
\end{tabular}

Measurements of optical density (O.D.) were made on autoradiographic films from tissuc scetions incubatcd with ${ }^{3} \mathrm{H}-$ 8-OH-DPAT ( $2 \mathrm{nM})$ or ${ }^{3} \mathrm{H}-5$-HT ( $\left.2 \mathrm{nM}\right)$. The ${ }^{3} \mathrm{H}$-ligand binding (expressed as O.D. units) to $5-\mathrm{HT}_{1 \mathrm{~A}}$ sites corresponded to total ${ }^{3} \mathrm{H}-8-\mathrm{OH}-\mathrm{DPAT}$ binding minus that persisting with $10 \mu \mathrm{M} 5-\mathrm{HT}$ (left-hand column) or to total ${ }^{3} \mathrm{H}-5-\mathrm{HT}$ binding minus that found when $0.1 \mu \mathrm{M}$ 8-OH-DPAT (middle column) or $1 \mu \mathrm{M}$ spiperone (right-hand column) was included in the incubation mixture. Each value is the mean O.D. \pm SEM of 24 measurements made in 4 rats for each assay condition. $r_{1}$, Coefficient of the correlation between ${ }^{3} \mathrm{H}-8-\mathrm{OH}-\mathrm{DPAT}$ binding and the ${ }^{3} \mathrm{H}-5-\mathrm{HT}$ binding component selectively inhibited by $0.1 \mu \mathrm{M}$ 8-OII-DPAT.

$r_{2}$, Correlation coefficient between the O.D. due to ${ }^{3} \mathrm{H}-5$-HT bound to 8-OH-DPAT $(0.1 \mu \mathrm{M})$-sensitive sites and the O.D. due to ${ }^{3} \mathrm{H}-5-\mathrm{HT}$ bound to spiperone $(1 \mu \mathrm{M})$-sensitive sites.

$r_{3}$, Correlation coefficient between ${ }^{3} \mathrm{H}-8-\mathrm{OH}-\mathrm{DPAT}$ binding and the ${ }^{3} \mathrm{H}-5-\mathrm{HT}$ binding component selectively inhibited by $1 \mu \mathrm{M}$ spiperone.

nd, Not detectable.

nation of an apparent $K_{\mathrm{d}}$ of $1.5 \mathrm{nM}$, similar to that found previously using hippocampal membranes, $K_{\mathrm{d}}=2-4$ nм (Gozlan et al., 1983; Ilall et al., 1985). As illustrated in Figurc 1, GTP $(0.5 \mathrm{~mm})$ markedly reduced, whereas $\mathrm{Mn}^{2+}\left(2 \mathrm{mM} \mathrm{MnCl}_{2}\right)$ enhanced ${ }^{3} \mathrm{H}-8-\mathrm{OH}-\mathrm{DPAT}$ specific binding to most brain regions. In contrast, the nonspecific binding that persisted when $10 \mu \mathrm{M}$ 5-HT was included in the incubation medium was unaffected by GTP or $\mathrm{Mn}^{2+}$. Indecd, the nonspecific binding was extremely low under all assay conditions (Fig. 1).

\section{Regional distribution of ${ }^{3} \mathrm{H}-8-\mathrm{OH}-\mathrm{DPAT}$ specific binding in rat brain: comparison with regional distribution of 8-OH-DPAT-sensitive ${ }^{3} \mathrm{H}-5-\mathrm{HT}$ binding}

Previous studies by our group (Marcinkiewicz et al., 1984) have shown that the localization of ${ }^{3} \mathrm{H}-8-\mathrm{OH}-D P A T$ binding sites is not superimposed over that of ${ }^{3} \mathrm{H}-5-\mathrm{HT}$ binding sites, notably in the substantia nigra, dorsal subiculum, choroid plexus, and striatum. Confirmation of these findings is shown in Figure 2. Thus, an intense labeling of these structures was obtained using ${ }^{3} \mathrm{H}-5-\mathrm{HT}$ (Fig. $2 B$ ) but not ${ }^{3} \mathrm{H}-8-\mathrm{OH}-\mathrm{DPAT}$ (Fig. $2 A$ ) as the ligand.

Since ${ }^{3} \mathrm{H}-5-\mathrm{HT}$ bound to all $5-\mathrm{HT}_{1}$ sites, whereas ${ }^{3} \mathrm{H}-8-\mathrm{OH}-$ DPAT bound solely to $5-\mathrm{HT}_{1 \mathrm{~A}}$ sites (Hamon et al., 1984b; Mid- dlemiss and Fozard, 1983), attempts were made to dissociate ${ }^{3} \mathrm{H}-5-\mathrm{HT}$ binding to $5-\mathrm{HT}_{1 \mathrm{~A}}$ sites from that to "non-5-HT sites with an appropriate concentration of "cold" 8-OH-DPAT. As shown in Figure $2 C$, the addition of $0.1 \mu \mathrm{M} 8-\mathrm{OH}-\mathrm{DPAT}$ to the incubation mixture resulted in a marked reduction of ${ }^{3} \mathrm{H}$ 5 -HT binding in those regions exhibiting ${ }^{3} \mathrm{H}-8-\mathrm{OH}-\mathrm{DPAT}$ binding capacity such as the entorhinal cortex, dorsal raphe nucleus, and dentate gyrus. In contrast, ${ }^{3} \mathrm{H}-5-\mathrm{HT}$ binding remaincd unaffected in the substantia nigra, dorsal subiculum, choroid plexus, and striatum (Fig. $2 C$ ). Since $0.1 \mu \mathrm{M}$ 8-OH-DPAT has been shown to saturate $5-\mathrm{HT}_{1 \mathrm{~A}}$ sites completely without altering ${ }^{3} \mathrm{H}$ 5-HT binding to $5-\mathrm{HT}_{1 \mathrm{~B}}$ sites (Hamon et al., 1984b), the data illustrated in Figure 2 indicate that $5-\mathrm{HT}_{1 \mathrm{~A}}$ sites could be identified either directly with ${ }^{3} \mathrm{H}-8-\mathrm{OH}-\mathrm{DPAT}$ as the ligand or indirectly as those where $0.1 \mu \mathrm{M} 8-\mathrm{OH}-\mathrm{DPAT}$ inhibited ${ }^{3} \mathrm{H}-5-\mathrm{HT}$ binding. Conversely, "non-5-HT " sites could be identified as those labeled by ${ }^{3} \mathrm{H}-5-\mathrm{HT}$ in the presence of $0.1 \mu \mathrm{M} 8-\mathrm{OH}-$ DPAT. Although these "non-5-HT ${ }_{1 \mathrm{~A}}$ " sites probably correspond to both 5-HT ${ }_{1 \mathrm{~B}}$ and 5-HT ${ }_{1 \mathrm{C}}$ sites (Pazos et al., 1984b), they are presently referred to as being mainly $5-\mathrm{HT}_{1 \mathrm{~B}}$ sites, since recent extensive autoradiographic studies by Pazos and Palacios (1985) have shown that the density of 5- $\mathrm{HT}_{1 \mathrm{C}}$ sites is low (usually less than $10 \%$ ) compared to that of other $5-\mathrm{HT}_{\mathrm{I}}$ sites in any region (except the choroid plexus) of the rat brain. 
Table 2. Regional distribution of $5-\mathrm{HT}_{1 \mathrm{~B}}$ binding sites in the rat brain

Specific ${ }^{3} \mathrm{H}-5-\mathrm{HT}$ binding to

5-HT ${ }_{1 B}$ sites (O.D.)

${ }^{3} \mathrm{H}-5-\mathrm{HT}+{ }^{3} \mathrm{H}-5-\mathrm{HT}+$

Brain structure

$0.1 \mu \mathrm{M} 8$-OH-DPAT $1 \mu \mathrm{M}$ spiperone

Substantia nigra

$0.132 \pm 0.012$

$0.106 \pm 0.017$

Choroid plexus ${ }^{a}$

$0.102 \pm 0.018$

$0.082 \pm 0.012$

Dorsal subiculum

$0.090 \pm 0.019$

Globus pallidus

$0.083 \pm 0.014$

$0.066 \pm 0.003$

$0.082 \pm 0.018$

Entorhinal cortex

$0.065 \pm 0.011$

$0.069 \pm 0.014$

Interpeduncular nucleus

$0.065 \pm 0.009$

Periaqueductal gray

Superior colliculus

Dorsal raphe nucleus

$0.061 \pm 0.012$

$0.060 \pm 0.009$

$0.058 \pm 0.010$

$0.068 \pm 0.016$

$0.067 \pm 0.015$

$0.054 \pm 0.013$

$0.056 \pm 0.014$

Lateral septum

Ventral hypothalamus

Dorsal hypothalamus

$0.057 \pm 0.004$

$0.057 \pm 0.010$

$0.055 \pm 0.009$

$0.054 \pm 0.005$

$0.049 \pm 0.011$

$0.052 \pm 0.004$

$0.045 \pm 0.010$

$0.044 \pm 0.006$

$0.043 \pm 0.009$

Central amygdala

Caudate-pulamen

$0.041 \pm 0.009$

$0.037 \pm 0.009$

$0.031 \pm 0.005$

$0.035 \pm 0.009$

Dentate gyrus

Parietal cortex

$0.030 \pm 0.006$

$0.033 \pm 0.008$

$0.029 \pm 0.005$

$0.026 \pm 0.009$

Frontal cortex

Hippocampal CA1

$0.025 \pm 0.003$

$0.028 \pm 0.006$

$0.019 \pm 0.002$

Hippocampal CA3

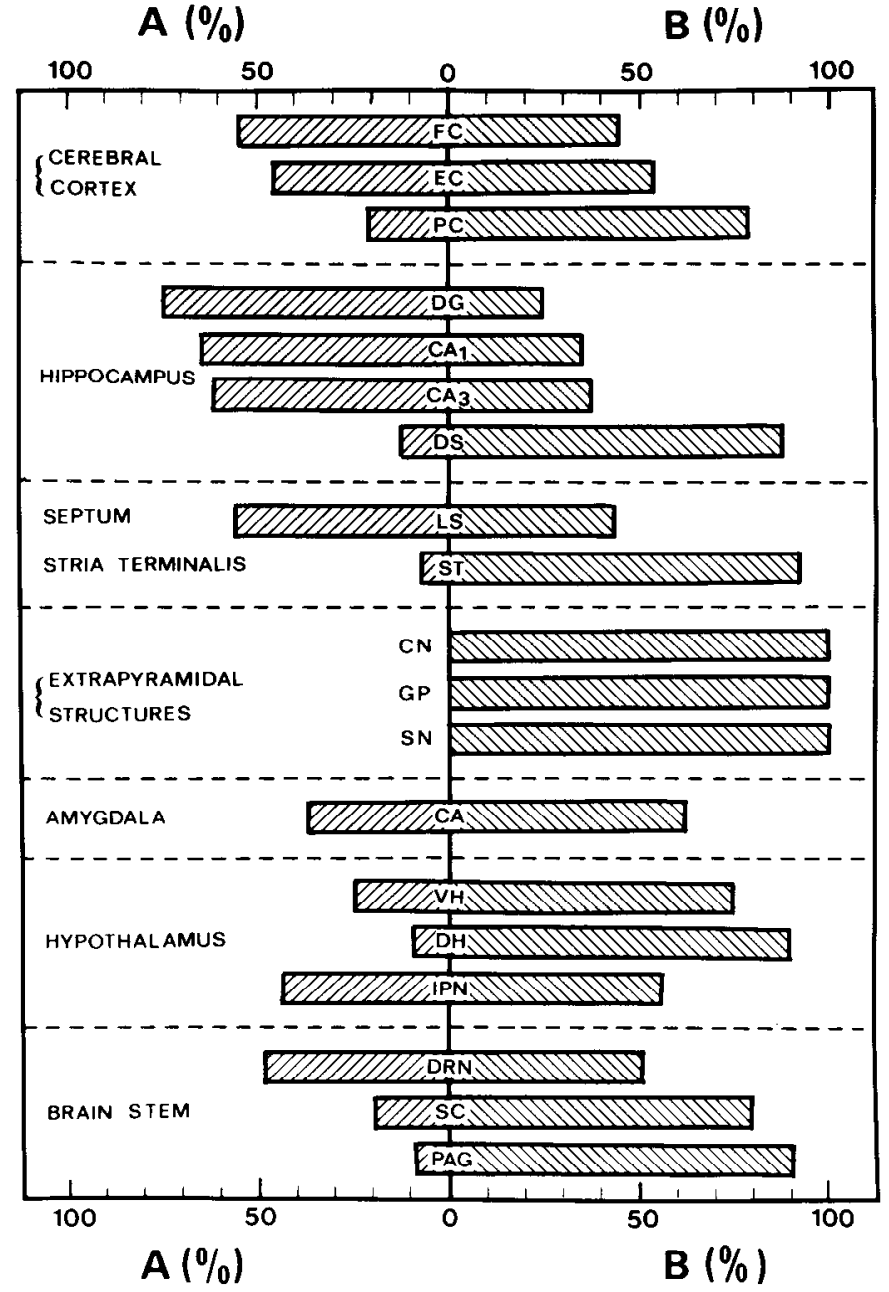

Figure 3. Respective proportions of 5- $\mathrm{HT}_{1 \mathrm{~A}}$ and $5-\mathrm{HT}_{1 \mathrm{~B}}$ binding sites in various brain areas. For each region examined, ${ }^{3} \mathrm{H}-5$ - $\mathrm{HT}$ binding to $5-\mathrm{HT}_{1 \mathrm{~A}}($ left $)$ or $5-\mathrm{HT}_{1 \mathrm{~B}}$ (right) sites is expressed as the percentage of total (specific) ${ }^{3} \mathrm{H}-5-\mathrm{HT}$ binding (to $5-\mathrm{HT}_{1}$ sites). Each bar is the mean of 12-24 separate determinations. Variations were less than 5\%. Abbreviations as in Figure 2.

sites, it can be inferred that the highest density of $5-\mathrm{HT}_{1 \mathrm{~B}}$ binding sites was found in the substantia nigra, followed by the dorsal subiculum and globus pallidus. Very low densities of 5-HT sites were detected in the hippocampus (gyrus dentatus $>$ $\mathrm{CA}_{1} \geq \mathrm{CA}_{3}$ ) and frontal and parietal cortex, and a fairly constant moderate density of $5-\mathrm{HT}_{1 \mathrm{~B}}$ sites was found in the other brain areas examined.

Respective proportions of $5-H T_{I A}$ and $5-H T_{I B}$ sites in various brain regions

Of the 19 regions examined, only 3 exhibited an apparently homogeneous population of $5-\mathrm{HT}_{1}$ sites, namely, the caudateputamen, globus pallidus, and substantia nigra, which contained exclusively a "non-5-HT ${ }_{1 \mathrm{~A}}$ " receptor type, probably the $5-\mathrm{HT}_{1 \mathrm{~B}}$ type (Fig. 3). A higher proportion of $5-\mathrm{HT}_{1 \mathrm{~B}}$ sites compared to $5-\mathrm{HT}_{1 \mathrm{~A}}$ sites occurred in the parietal cortex, dorsal subiculum, stria terminalis, central amygdala, hypothalamic areas, superior colliculi, and periaqueductal gray. In contrast, hippocampal areas (dentate gyrus, $\mathrm{CA}_{1}, \mathrm{CA}_{3}$ ) contained more $5-\mathrm{HT}_{1 \mathrm{~A}}$ sites than $5-\mathrm{HT}_{\mathrm{IB}}$ sites, and other regions (cerebral cortex, lateral septum, interpeduncular nucleus, dorsal raphe nucleus) had approxi-

mately similar proportions of the 2 binding sites (Fig. 3).

\section{5-HT $T_{1 B}$ sites}

As indicated in Table 2, the regional distributions of specific sites labeled by ${ }^{3} \mathrm{H}-5-\mathrm{HT}$ in the presence of $0.1 \mu \mathrm{M} 8-\mathrm{OH}$-DPAT or $1 \mu \mathrm{M}$ spiperone were very similar $(r=0.98)$. Since these sites corresponded mainly (if not exclusively, see above) to $5-\mathrm{HT}_{1 \mathrm{~B}}$ 


\begin{tabular}{|c|c|c|}
\hline \multirow[b]{2}{*}{ Structures } & \multicolumn{2}{|c|}{ Specific ${ }^{3} \mathrm{H}-5-\mathrm{HT}$ binding (O.D. units) } \\
\hline & - & $+0.1 \mu \mathrm{M}$ LSD $(\%)$ \\
\hline \multicolumn{3}{|c|}{ Brain regions enriched in $5-\mathrm{HT}_{1 \mathrm{~A}}$ sites } \\
\hline Lateral septum & $0.130 \pm 0.009$ & $0.019 \pm 0.006(15)$ \\
\hline Dentate gyrus & $0.124 \pm 0.008$ & $0.008 \pm 0.003(6)$ \\
\hline Dorsal raphe nucleus & $0.118 \pm 0.012$ & $0.013 \pm 0.002(11)$ \\
\hline \multicolumn{3}{|c|}{ Brain regions enriched in $5-\mathrm{HT}_{1 \mathrm{~B}}$ sites } \\
\hline Substantia nigra & $0.128 \pm 0.009$ & $0.056 \pm 0.008(44)$ \\
\hline Dorsal subiculum & $0.102 \pm 0.006$ & $0.056 \pm 0.006(55)$ \\
\hline Globus pallidus & $0.089 \pm 0.009$ & $0.047 \pm 0.004(53)$ \\
\hline Choroid plexus & $0.104 \pm 0.014$ & $0.016 \pm 0.005(15)$ \\
\hline
\end{tabular}

Adjacent coronal sections were incubated with $2 \mathrm{~nm}{ }^{3} \mathrm{H}-5-\mathrm{HT}$ in the absence or presence of $0.1 \mu \mathrm{M}$ LSD. Autoradiograms were analyzed by microdensitometry, and the results are the means \pm SEM of O.D. measurements in 6-10 sections from 2-4 rats. Background (incubations in the presence of $10 \mu \mathrm{M} 5 \cdot \mathrm{HT}$ ) was subtracted from all values.

Figures in parentheses are the percentages of specifically bound ${ }^{3} \mathrm{H}-5-\mathrm{HT}$ (in O.D. units) that persisted in the presence of $0.1 \mu \mathrm{M}$ LSD compared to respective controls.

\section{The case of the choroid plexus}

Since ${ }^{3} \mathrm{H}-8-\mathrm{OH}-\mathrm{DPAT}$ did not bind to the choroid plexus (Table 1), whereas ${ }^{3} \mathrm{H}-5-\mathrm{HT}$ gave an intense labeling that was reduced neither by $0.1 \mu \mathrm{M} 8-\mathrm{OH}$-DPAT nor by $1 \mu \mathrm{M}$ spiperone (Table 2 ), it may be that $5-\mathrm{HT}_{1}$ sites in the choroid plexus belonged to the 5-HT ${ }_{1 \mathrm{~B}}$ type. However, experiments with "cold" LSD $(0.1$ $\mu \mathrm{M})$ as the displacing agent suggested that the situation was probably more complex.

Using ${ }^{3} \mathrm{H}-8-\mathrm{OH}-\mathrm{DPAT}$ as the ligand, almost no binding $(<10 \%$ of control) persisted in any brain area examined when $0.1 \mu \mathrm{M}$ LSD was added to the incubation medium (not shown). In contrast, the inhibitory effect of LSD on ${ }^{3} \mathrm{H}-5-\mathrm{HT}$ binding exhibited marked regional differences. Almost complete inhibition was observed in areas containing mostly $5-\mathrm{HT}_{1 \mathrm{~A}}$ sites (Table 3 ) whereas approximately $50 \%$ inhibition took place in brain regions enriched in 5- $\mathrm{HT}_{\mathrm{B}}$ sites (Table 3). Surprisingly, $0.1 \mu \mathrm{M}$ LSD markedly inhibited $(-85 \%){ }^{3} \mathrm{H}-5$-HT binding to specific sites in the choroid plexus (Table 3), where, however, neither 8-OH-DPAT nor spiperone bound, as expected for $5-\mathrm{HT}_{1 \mathrm{~B}}$ sites.

\section{Effects of reserpine treatment or 5,7-HT-induced lesion on ${ }^{3} \mathrm{H}-8-O H-D P A T$ and ${ }^{3} H-5-H T$ specific binding to $5-H T_{1 A}$ and $5-H T_{1 B}$ sites in various brain regions}

Twenty-four hours after the i.p. administration of reserpine (10 $\mathrm{mg} / \mathrm{kg}$ ), 5-HT levels in the cerebral cortex, hippocampus, and striatum were less than $5 \%$ of those found in control rats $(0.38 \pm$ $0.04,0.45 \pm 0.03$, and $0.43 \pm 0.04 \mu \mathrm{g} / \mathrm{g}$, respectively; $n=6$ in each case). However, O.D. measurements on autoradiographic films from tissue sections incubated with $2 \mathrm{nM}^{3} \mathrm{H}-8-\mathrm{OH}-\mathrm{DPAT}$ or ${ }^{3} \mathrm{H}-5-\mathrm{HT}$ did not reveal any significant difference between control and reserpine-treated rats in the 20 areas examined (data not shown).

The intracerebral injection of 5,7-HT $(8 \mu \mathrm{g})$ resulted in a 80 $90 \%$ reduction in tryptophan hydroxylase activity and 5-HT levels in the hippocampus and cerebral cortex on the injected (right) side. A marked decrease $(-70$ to $-80 \%)$ in these 2 serotoninergic markers was also noted in the contralateral hippocampus and cerebral cortex. Tryptophan hydroxylase activity and 5-HT levels were also diminished in both striata (right, $-72 \%$; left, $-60 \%)$ and in the anterior raphe area $(-52 \%)$ of 5,7-HT-lesioned rats. Autoradiograms obtained after incubation of brain slices with either ${ }^{3} \mathrm{H}-5-\mathrm{HT}$ alone (for all $5-\mathrm{HT}_{1}$
Table 4. ${ }^{3} \mathrm{H}-5-\mathrm{HT}$ and ${ }^{3} \mathrm{H}-8-\mathrm{OH}-\mathrm{DPAT}$ binding to the substantia nigra and dorsal raphe nucleus of control or 5,7-HT-treated rats

\begin{tabular}{|c|c|c|c|}
\hline \multirow[b]{3}{*}{ Structures } & \multicolumn{3}{|c|}{ Specific ${ }^{3} \mathrm{H}$-ligand binding (O.D. units) } \\
\hline & \multicolumn{2}{|l|}{${ }^{3} \mathrm{H}-5-\mathrm{HT}$} & \multirow[b]{2}{*}{${ }^{3} \mathrm{H}-8-\mathrm{OH}-\mathrm{DPAT}$} \\
\hline & - & $\begin{array}{l}+0.1 \mu \mathrm{M} \\
\text { 8-OH-DPAT }\end{array}$ & \\
\hline \multicolumn{4}{|c|}{ Dorsal raphe nucleus } \\
\hline Control & $0.120 \pm 0.014$ & $0.061 \pm 0.007$ & $0.267 \pm 0.032$ \\
\hline $5,7-\mathrm{HT}$ & $\begin{array}{l}0.064^{a}+0.010 \\
(-47 \%)\end{array}$ & $\begin{array}{l}0.054+0.010 \\
(-11 \%)\end{array}$ & $\begin{array}{l}0.106^{a} \pm 0.013 \\
(-60 \%)\end{array}$ \\
\hline \multicolumn{4}{|c|}{ Substantia nigra } \\
\hline Control & $0.118 \pm 0.010$ & $0.132 \pm 0.012$ & - \\
\hline 5,7-HT & $\begin{array}{l}0.091^{a} \pm 0.010 \\
(-23 \%)\end{array}$ & $\begin{array}{l}0.083^{a} \pm 0.014 \\
(-37 \%)\end{array}$ & - \\
\hline
\end{tabular}

Optical densities were measured on autoradiographic films from tissue sections incubated with $2 \mathrm{nM}^{3} \mathrm{H}-5-\mathrm{HT}$ or $2 \mathrm{nM}^{3} \mathrm{H}-8-\mathrm{OH}$-DPAT for the selective labeling of all 5-HT, sites (with ${ }^{3} \mathrm{H}-5-\mathrm{HT}$ alone, left-hand column), "non-5-HT iA $_{1}$ sites, i.e., mainly 5-HT ${ }_{1 \mathrm{~B}}$ sites (with ${ }^{3} \mathrm{H}-5$-HT plus $0.1 \mu \mathrm{M}$ 8-OH-DPAT, middle column), or $5-\mathrm{HT}_{1 \mathrm{~A}}$ sites (with ${ }^{3} \mathrm{H}-8-\mathrm{OH}-\mathrm{DPAT}$, right-hand column). Results are the means \pm SEM of O.D. measurements in 12-24 sections from 4 rats in each group. Background was subtracted from all values.

Figures in parentheses are the percentage reductions due to 5,7-HT treatment.

${ }^{a} p<0.05$ compared to the respective control values (Student's $t$ test).

sites), ${ }^{3} \mathrm{H}-5-\mathrm{HT}$ in the presence of $0.1 \mu \mathrm{M}$ 8-OH-DPAT (for "non-5-HT 1 " sites), or ${ }^{3} \mathrm{H}-8-\mathrm{OH}-\mathrm{DPAT}$ (for 5-HT $1 \mathrm{~A}$ sites) revealed that the 5,7-HT lesion affected none of these binding sites in most areas studied. However, 2 exceptions were noted: the dorsal raphe nucleus and the substantia nigra (Table 4). A marked decrease in ${ }^{3} \mathrm{H}-8-\mathrm{OH}-\mathrm{DPAT}$ and ${ }^{3} \mathrm{H}-5-\mathrm{HT}$ binding was noted in the dorsal raphe nucleus of 5,7-HT-treated rats (Fig. 4 , Table 4). However, when ${ }^{3} \mathrm{H}-5-\mathrm{HT}$ binding assays were performed in the presence of $0.1 \mu \mathrm{M} 8$-OH-DPAT, no significant difference could be detected between control and lesioned animals (Fig. 4, Table 4). Similarly, ${ }^{3} \mathrm{H}-5-\mathrm{HT}$ binding in the presence of $1 \mu \mathrm{M}$ spiperone remained unaltered in 5,7-HT-treated rats compared to control animals (not shown).

The second exception concerned the substantia nigra, where a significant reduction of ${ }^{3} \mathrm{H}-5-\mathrm{HT}$ binding (to "non-5-HT ${ }_{1 \mathrm{~A}}$," i.e., to $5-\mathrm{HT}_{1 \mathrm{~B}}$ sites) was found bilaterally in 5,7-HT-lesioned rats (Table 4).

\section{Discussion}

Numerous investigations have shown that quantitative autoradiography is a reliable technique with which to study the binding of labeled ligands to specific recognition sites in tissues, especially in the gray matter regions within the CNS (Pazos and Palacios, 1985; Pazos et al., 1984a; Rainbow et al., 1982, 1984). The present study further confirms this conclusion, since application of the autoradiographic technique to examination of the properties of ${ }^{3} \mathrm{H}-8-\mathrm{OH}-\mathrm{DPAT}$ binding to $5-\mathrm{HT}_{1 \mathrm{~A}}$ sites in brain gave the same results as those previously found using brain membranes. In particular, we observed that these $5-\mathrm{HT}_{1 \mathrm{~A}}$ binding sites have a $K_{\mathrm{d}}$ of $1.5 \mathrm{nM}$ and are modulated in opposite directions by GTP and $\mathrm{Mn}^{2+}$, in agreement with recent observations by Hall et al. (1985). However, binding studies with membranes allowed the detection of another class of specific sites for ${ }^{3} \mathrm{H}-8$-OH-DPAT, particularly in the striatum (Gozlan el al., 1983; Hall et al., 1985), where we failed to find any specific binding of this ligand using the present autoradiographic approach. Indeed, striatal sites have a lower affinity $\left(K_{\mathrm{d}} \sim 10 \mathrm{nM}\right)$ than $5-\mathrm{HT}_{\mathrm{IA}}$ sites for ${ }^{3} \mathrm{H}-8-\mathrm{OH}-\mathrm{DPAT}$, and the dissociation of this ligand is much faster from the striatal sites (Hall et al., 1985). Therefore, the present incubation conditions were not appropriate for the specific labeling of striatal sites by ${ }^{3} \mathrm{H}-8-\mathrm{OH}-$ 


\section{CONTROL $\quad 5,7-\mathrm{HT}$}

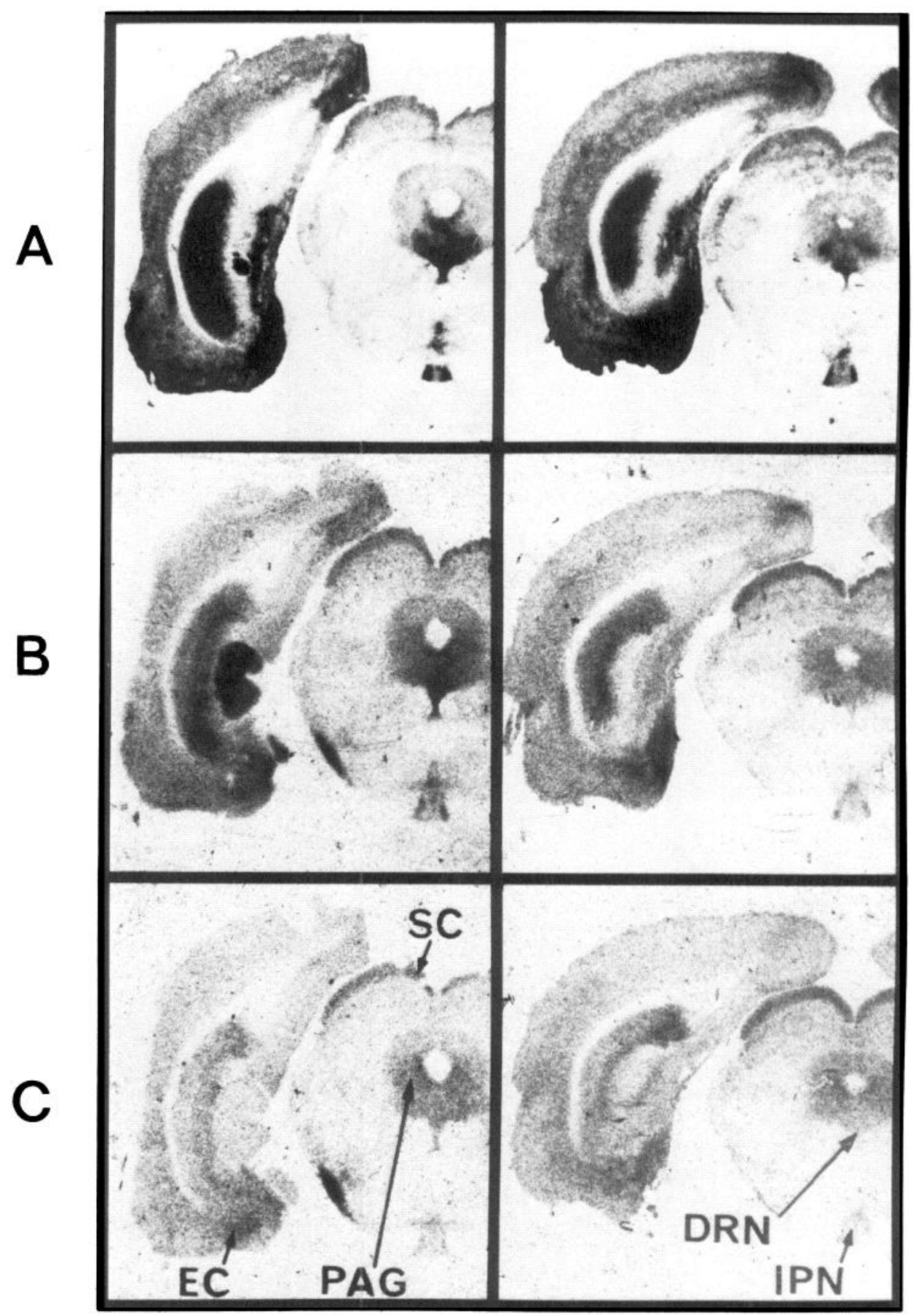

Figure 4. Autoradiograms of ${ }^{3} \mathrm{H}-8$ $\mathrm{OH}-\mathrm{DPAT}$ and ${ }^{3} \mathrm{H}-5-\mathrm{HT}$ binding to the dorsal raphe nucleus of a control or a 5,7-HT-treated rat. Coronal sections were taken at $\mathrm{A}=-7.0 \mathrm{~mm}$ from the bregma (Paxinos and Watson, 1982). $A,{ }^{3} \mathrm{H}-8-\mathrm{OH}-\mathrm{DPAT}$ binding. $B,{ }^{3} \mathrm{H}-5-\mathrm{HT}$ binding. $C,{ }^{3} \mathrm{H}-5-\mathrm{HT}$ binding in the presence of $0.1 \mu \mathrm{M}$ 8-OH-DPAT. Abbreviations as in Figure 2. Similar results were obtained in 4 rats in each group.

DPAT. Attempts to reveal ${ }^{3} \mathrm{H}-8-\mathrm{OH}-\mathrm{DPAT}$ striatal sites using higher concentrations of the labeled ligand (8-12 nM) and less extensive washing procedure were largely unsuccessful due to the high level of nonspecific binding found on autoradiographic films under such conditions (unpublished observations).

Detailed microdensitometric analysis of the brain regions, where bound ${ }^{3} \mathrm{H}-5$-HT could be displaced by $0.1 \mu \mathrm{M} 8$-OH-DPAT or $1 \mu \mathrm{M}$ spiperone, indicated that they superimposed exactly with those selectively labeled by nanomolar concentrations of ${ }^{3} \mathrm{H}-8-\mathrm{OH}$-DPAT. Since previous studies using brain membranes (Hall et al., 1985; Hamon et al., 1984b; Middlemiss and Fozard,
1983) demonstrated that the ${ }^{3} \mathrm{H}-5-\mathrm{HT}$ binding component that can be displaced by $0.1 \mu \mathrm{M} 8$-OH-DPAT corresponds in fact to the $5-\mathrm{HT}_{1 \mathrm{~A}}$ sites previously defined by Nelson et al. (1980), the present observations confirm that ${ }^{3} \mathrm{H}-8-\mathrm{OH}-\mathrm{DPAT}$ can be used directly for the selective labeling of these sites in brain sections (see Marcinkiewicz et al., 1984; Pazos and Palacios, 1985; Vergé et al., 1985). Conversely, ${ }^{3} \mathrm{H}-5-\mathrm{HT}$ binding, which persisted in the presence of $0.1 \mu \mathrm{M} 8-\mathrm{OH}-\mathrm{DPAT}$, involved the second main class of 5-HT, sites, i.e., the 5-HT 1 type (Nelson et al., 1980). Some contribution of 5-HT $\mathrm{HC}_{1 \mathrm{C}}$ sites was also probable under this condition, but the density of 5-HT $\mathrm{HC}_{1 \mathrm{C}}$ sites was so low compared 
to that of $5-\mathrm{HT}_{1 \mathrm{~B}}$ sites in most brain regions (Pazos and Palacios, 1985 ) that these "non-5-HT ${ }_{1 \mathrm{~A}}$ " sites in fact corresponded (almost exclusively) to $5-\mathrm{HT}_{1 \mathrm{~B}}$ sites. In agreement with this conclusion, examination of the displacement by $0.1 \mu \mathrm{M}$ LSD of ${ }^{3} \mathrm{H}-$ 5-HT specifically bound to "non-5- $\mathrm{HT}_{1 \mathrm{~A}}$ " sites revealed that, except in the choroid plexus where 5-HT $\mathrm{HC}_{1 \mathrm{C}}$ sites exist (Pazos and Palacios, 1985), LSD action in all brain areas considered resembled that found in the globus pallidus (Table 3 and data not shown), where $5-\mathrm{HT}_{1 \mathrm{~B}}$ sites predominate (Pazos and Palacios, 1985).

Owing to the selective labeling of $5-\mathrm{HT}_{1 \mathrm{~A}}$ sites by ${ }^{3} \mathrm{H}-8-\mathrm{OH}-$ DPAT and of $5-\mathrm{HT}_{1 \mathrm{~B}}$ sites by ${ }^{3} \mathrm{H}-5-\mathrm{HT}$ in the presence of 0.1 $\mu \mathrm{M} 8$-OH-DPAT (or $1 \mu \mathrm{M}$ spiperone), the respective distributions of these 2 binding classes could be examined in detail. In general, 5- $\mathrm{HT}_{1 \mathrm{~A}}$ sites are less widely distributed than the $5-\mathrm{HT}_{1 \mathrm{~B}}$ sites, and only a few areas contain more $5-\mathrm{HT}_{1 \mathrm{~A}}$ than $5-\mathrm{HT}_{1 \mathrm{~B}}$ sites: hippocampus, lateral septum, frontal cortex; however, none of these can be considered as a "pure" region with regard to the $5-\mathrm{HT}_{1 \mathrm{~A}}$ binding class. In contrast, several areas, notably the substantia nigra, globus pallidus, and caudate-putamen, contain only "non-5-HT ${ }_{1 \mathrm{~A}}$ ", i.e., 5-HT $\mathrm{HB}_{1 \mathrm{~B}}$ sites. The choroid plexus exhibited no ${ }^{3} \mathrm{H}-8-\mathrm{OH}-\mathrm{DPAT}$ binding but was intensely labeled by ${ }^{3} \mathrm{H}-5-\mathrm{HT}$ (in the absence or presence of $0.1 \mu \mathrm{M} 8-\mathrm{OH}-\mathrm{DPAT}$ ), as expected for a structure containing only $5-\mathrm{HT}_{1 \mathrm{~B}}$ sites. However, further observations indicated that the properties of 5-HT sites in the choroid plexus are distinct from those of 5-HT sites in brain tissues. Thus, using $\operatorname{LSD}(0.1 \mu \mathrm{M})$ as a displacing drug, we noted that ${ }^{3} \mathrm{H}-5-\mathrm{HT}$ binding was almost completely inhibited in regions containing mostly $5-\mathrm{HT}_{1 \mathrm{~A}}$ sites bul only partially in those enriched in $5-\mathrm{HT}_{1 \mathrm{~B}}$ sites. Therefore, LSD can be considered as a ligand acting preferentially at $5-\mathrm{HT}_{1 \mathrm{~A}}$ sites. Surprisingly, LSD $(0.1 \mu \mathrm{M})$ also suppressed ${ }^{3} \mathrm{H}-5-\mathrm{HT}$ binding to choroid plexus, in contrast to that expected from the existence of 5-HT ${ }_{1 \mathrm{~B}}$ sites in this structure. Accordingly, the 5-HT $\mathrm{H}_{1}$ sites labeled by ${ }^{3} \mathrm{H}-5-\mathrm{HT}$ in the choroid plexus probably correspond neither to $5-\mathrm{HT}_{1 \mathrm{~A}}$ nor to $5-\mathrm{HT}_{1 \mathrm{~A}}$ sites. These results support the recent findings of Pazos et al., who proposed calling these binding sites 5-HT ${ }_{I C}$ (Pazos et al., 1984b; Pazos and Palacios, 1985).

The preferential location of $5-\mathrm{HT}_{1 \mathrm{~A}}$ binding sites in limbic regions (hippocampus, septum, etc.) might suggest that the selective 5-HT ${ }_{1 \mathrm{~A}}$ agonist 8-OH-DPAT would influence behaviors depending on the "limbic brain" (Gray, 1982). Indeed, anxiolytic (-like) (Engel et al., 1984) and antidepressant (-like) (Curzon et al., 1985) cffcets of 8-OH-DPAT have been described in rats. Furthermore, new anxiolytic drugs such as buspirone and TVX Q 7821 (isapirone) have recently been shown to act in the nanomolar range on $5-\mathrm{HT}_{1 \mathrm{~A}}$ binding sites in the hippocampus (Glaser and Traber, 1983; Glaser et al., 1985; Gozlan et al., 1983). It is therefore highly probable that $5-\mathrm{HT}_{1 \mathrm{~A}}$ binding sites in limbic regions participate in the regulation of behaviors such as those associated to affective experience and emotion (see Trimble and Zarifian, 1984).

In contrast, $5-\mathrm{HT}_{1 \mathrm{~B}}$ sites are particularly concentrated in the extrapyramidal areas (caudate-putamen, globus pallidus, etc.) involved in the control of motor function (Dray, 1979). Interestingly, a marked hyperlocomotion is usually observed following the administration of RU 24969 (Hunt and Oberlander, 1981), a 5-HT agonist possibly acting preferentially on $5-\mathrm{HT}_{1 \mathrm{~B}}$ sites (Doods et al., 1985; Sills et al., 1984). However, 5-HT sites also exist outside extrapyramidal areas (see Fig. 3), and probably participate in the control of other central functions in addition to motor function. Similarly, $5-\mathrm{HT}_{1 \mathrm{~A}}$ sites are found not only in limbic areas, but also in extralimbic regions. Therefore, it would be an obvious oversimplification to consider that 5-HT ${ }_{\text {IA }}$ sites are exclusively involved in the control of specific behaviors associated with emotion and affect.

A well-known function of some 5-HT receptors, namely those located presynaptically on serotoninergic cell bodies and/or den- drites (Aghajanian, 1981; De Montigny et al., 1984) and terminals (Göthert, 1980), consists of triggering feedback mechanisms that exert a negative influence on the nerve impulse flow and the neurotransmitter release process in these neurons. Recently, Engel et al. (1983) and Middlemiss (1984) proposed that the presynaptic autoreceptors located on serotoninergic terminals may correspond to $5-\mathrm{HT}_{1 \mathrm{~B}}$ sites, and direct demonstration of this hypothesis has been attempted in the present study by examining the fate of $5-\mathrm{HT}_{1 \mathrm{~B}}$ (and $5-\mathrm{HT}_{1 \mathrm{~A}}$ ) sites following the selective degeneration of serotoninergic neurons in 5,7-HTtreated rats. However, the only region where ${ }^{3} \mathrm{H}-5-\mathrm{HT}$ binding to $5-\mathrm{HT}_{1 \mathrm{~B}}$ sites was significantly reduced following the lesion was the substantia nigra. This change could not be ascribed to some artifactual alteration due to the disappearance of endogenous 5-HT in this structure, since the marked 5-HT depletion following reserpine treatment was not associated with any modification of ${ }^{3} \mathrm{H}-8-\mathrm{OH}-\mathrm{DPAT}$ or ${ }^{3} \mathrm{H}-5-\mathrm{HT}$ binding to $5-\mathrm{HT}_{1 \mathrm{~A}}$ and $5-\mathrm{HT}_{1 \mathrm{~B}}$ sites in all regions examined. Therefore, the loss of 5-HT sites in the substantia nigra was probably the consequence of the local degeneration of serotoninergic terminals. Whether such sites correspond to the presynaptic autoreceptors (Engel et al., 1983; Middlemiss, 1984) is, however, far from being proved, as no loss of $5-\mathrm{HT}_{1 \mathrm{~B}}$ sites occurred in such other regions as the striatum, hypothalamus, and cerebral cortex, where presynaptic autoreceptors controlling 5-HT release have been found (see Hamon et al., 1984a, b). It is therefore more likely that 5-HT autoreceptors located on presynaptic serotoninergic terminals are neither $5-\mathrm{HT}_{\mathrm{IA}}$ nor $5-\mathrm{HT}_{1 \mathrm{~B}}$ sites but correspond to other sites with distinct pharmacological properties (see Gozlan et al., 1983). The situation was much clearer at the level of serotoninergic cell bodies and/or dendrites within the dorsal raphe nucleus, since a marked reduction of ${ }^{3} \mathrm{H}-8-\mathrm{OH}-D P A T$ or ${ }^{3} \mathrm{H}-5$ $\mathrm{HT}$ binding to $5-\mathrm{HT}_{1 \mathrm{~A}}$ sites was observed following intracerebral administration of 5,7-HT. Since this treatment induced a parallel local decrease in tryptophan hydroxylase activity, it can be postulated that the $5-\mathrm{HT}_{1 \mathrm{~A}}$ binding sites that disappeared were associated with tryptophan hydroxylase-containing neurons, i.e., corresponded to the presynaptic 5-HT autoreceptors located on serotoninergic cell bodies and/or dendrites. Interestingly, in addition to 5-HT itself, which is released locally, very probably from 5-HT cell bodies and dendrites (Bourgoin et al., 1981; Héry et al., 1986), 5-HT ${ }_{1 \mathrm{~A}}$ agonists are especially active on these presynaptic autoreceptors and trigger a marked reduction of the ncrve impulsc flow within scrotonincrgic raphe neurons (De Montigny et al., 1984; Eison et al., 1984; Sprouse and Aghajanian, 1985). Therefore, these reported pharmacological observations, as well as the present anatomical evidence, support the contention that the 5-HT autoreceptors located on cell bodies and/or dendrites of serotoninergic raphe ncurons are of the $5-\mathrm{HT}_{1 \mathrm{~A}}$ type.

\section{References}

Aghajanian, G. K. (1981) The modulatory role of serotonin multiple receptors in brain. In Serotonin Neurotransmission and Behavior, B. L. Jacobs and A. Gelperin, eds., pp. 156-185, MIT Press, Cambridge, MA.

Blackburn, T. P., J. D. Kemp, D. A. Martin, and B. Cox (1984) Evidence that 5-HT agonist-induced rotational behavior in the rat is mediated via 5-HT, receptors. Psychopharmacology 83: 163-165.

Bourgoin, S., P. Soubrié, F. Artaud, T. D. Reisine, and J. Glowinski (1981) Control of 5-HT release in the striatum and the substantia nigra of the cat. J. Physiol. (Paris) 77: 303-307.

Curzon, G., C. T. Dourish, and G. A. Kennett (1985) The 5-HT agonist 8-OH-DPAT attenuates stress-induced deficits in open field activity and feeding behaviour. Br. J. Pharmacol. (in press).

De Montigny, C., P. Blier, and Y. Chaput (1984) Electrophysiologically-identified serotonin receptors in the rat CNS. Effect of antidepressant treatment. Neuropharmacology 23: 1511-1520.

Doods, H. N., H. O. Kalkman, A. DeJonge, M. J. M. C. Thoolen, B. 
Wilffert, P. B. M. W. M. Timmermans, and P. A. Van Zwieten (1985) Differential selectivities of RU 24969 and 8-OH-DPAT for the purported 5-HT $\mathrm{HA}_{1 \mathrm{~A}}$ and $5-\mathrm{HT}_{1 \mathrm{~B}}$ binding sites. Correlation between 5-HT affinity and hypotensive activity. Eur. J. Pharmacol. 112: 363-370.

Dray, A. (1979) The striatum and substantia nigra: A commentary on their relationship. Neuroscience 4: 1407-1439.

Eison, M. S., D. P. Taylor, A. S. Eison, C. P. Van der Maelen, L. A. Riblet, and D. L. Temple (1984) Pharmacologic effects of chronic administration of the non-benzodiazepine antidepressant-anxiolytic candidate, BMY 13805. Soc. Neurosci. Abstr. 10:259.

Emerit, M. B., H. Gozlan, M. D. Hall, M. Hamon, and A. Marquet (1985) Irreversible blockade of central 5-HT binding sites by 8-methoxy-2'-chloro-PAT. Biochem. Pharmacol. 34: 883-892.

Engel, G., M. Göthert, E. Müller-Schweinitzer, E. Schlicker, L. Sistonen, and P. A. Stadler (1983) Evidence for common pharmacological properties of $\left({ }^{3} \mathrm{H}\right)$ 5-hydroxytryptamine binding sites, presynaptic 5-hydroxytryptamine autoreceptors in CNS and inhibitory presynaptic 5-hydroxytryptamine receptors on sympathetic nerves. Naunyn Schmiedeberg's Arch. Pharmacol. 324: 116-124.

Engel, J. A., S. Hjorth, K. Svensson, A. Carlsson, and S. Liljequist (1984) Anticonflict effect of the putative serotonin receptor agonist 8-hydroxy-2-(di-n-propylamino) tetralin (8-OH-DPAT). Eur. J. Pharmacol. 105: 365-368.

Glaser, T., and J. Traber (1983) Buspirone: Action on serotonin receptors in calf hippocampus. Eur. J. Pharmacol. 88: 137-138.

Glaser, T., M. Rath, J. Traber, K. Zilles, and A. Schleicher (1985) Autoradiographic identification and topographical analyses of high affinity serotonin receptor subtypes as a target for the novel putative anxiolytic TVX Q7821. Brain Res. 358: 129-136.

Göthert, M. (1980) Serotonin-receptor-mediated modulation of $\mathrm{Ca}^{2+}$ dependent 5-hydroxytryptamine release from neurons of the rat brain cortex. Naunyn Schmiedebergs Arch. Pharmacol. 314: 223-230.

Gozlan, H., S. El Mestikawy, L. Pichat, J. Glowinski, and M. Hamon (1983) Identification of presynaptic 5-HT autoreceptors using a new ligand: ${ }^{3} \mathrm{H}-\mathrm{PAT}$. Nature 305 : 140-142.

Gray, J. A. (1982) The Neuropsychology of Anxiety: An Enquiry into the Functions of the Septo-hippocampal System, Clarendon Press, Oxford, U.K

Hall, M. D., S. El Mestikawy, M. B. Emerit, L. Pichat, M. Hamon, and H. Gozlan (1985) $\left({ }^{3} \mathrm{H}\right)$ 8-hydroxy-2-(di-n-propylamino)tetralin binding to pre- and postsynaptic 5-hydroxytryptamine sites in various regions of the rat brain. J. Neurochem. 44: 1685-1696.

Hamon, M., S. Bourgoin, J. Jagger, and J. Glowinski (1974) Effects of LSD on synthesis and release of 5-HT in rat brain slices. Brain Res. 69: 265-280.

Hamon, M., D. L. Nelson, M. Mallat, and S. Bourgoin (1981) Are 5 -HT receptors involved in the sprouting of serotoninergic terminals following neonatal 5,7-dihydroxytryptamine treatment in the rat? Neurochem. Int. 3: 69-79.

Hamon, M., S. Bourgoin, S. El Mestikawy, and C. Goetz (1984a) Central serotonin receptors. In Handbook of Neurochemistry, Vol. 6, 2nd ed., A. Lajtha, ed., pp. 107-143, Plenum, New York.

Hamon, M., S. Bourgoin, H. Gozlan, M.D. Hall, C. Goetz, F. Artaud, and A. S. Horn (1984b) Biochemical evidence for the 5-HT agonist properties of PAT (8-hydroxy-2(di-n-propylamino)tetralin) in the rat brain. Eur. J. Pharmacol. 100: 263-276.

Héry, F., M. Faudon, and C. Fueri (1986) Release of serotonin in structures containing serotoninergic nerve cell bodies: Dorsalis raphe nucleus and nodose ganglia of the cat. Ann. NY Acad. Sci. (in press).

Hunt, P., and C. Oberlander (1981) The interaction of indole derivatives with the serotonin receptor and non-dopaminergic circling behavior. In Serotonin: Current Aspects of Neurochemistry and Function, B. Haber, S. Gabay, M. R. Issidorides, and S. G. A. Alivisatos, eds., pp. 547-562, Plenum, New York.

Leysen, J. E. (1984) Problems in in vitro receptor binding studies and identification and role of serotonin receptor sites. Neuropharmacology $23: 247-254$.

Leysen, J. E., C. J. E. Niemegeers, J. M. Van Nueten, and P. M. Laduron (1982) ${ }^{3} \mathrm{H}$-ketanserin ( $\mathrm{R} \mathrm{41468)}$ ), a selective ${ }^{3} \mathrm{H}$-ligand for serotonin ${ }_{2}$ receptor binding sites. Binding properties, brain distribution, and functional role. Mol. Pharmacol. 21: 301-314.

Lucki, I., M. S. Nobler, and A. Frazer (1984) Differential actions of serotonin antagonists on two behavioral models of serotonin receptor activation in the rat. J. Pharmacol. Exp. Ther. 228: 133-139.

Marcinkiewicz, M., D. Vergé, H. Gozlan, L. Pichat, and M. Hamon (1984) Autoradiographic evidence for the heterogeneity of $5-\mathrm{HT}_{1}$ sites in the rat brain. Brain Res. 291: 159-163.

Middlemiss, D. N. (1984) 8-Hydroxy-2-(di-n-propylamino)tetralin is devoid of activity at the 5-hydroxytryptaminc autorcceptor in rat brain. Implications for the proposed link between the autoreceptor and the $\left({ }^{3} \mathrm{H}\right) 5-\mathrm{HT}$ recognition site. Naunyn Schmiedeberg's Arch. Pharmacol. 327: 18-22.

Middlemiss, D. N., and J. R. Fozard (1983) 8-Hydroxy-2-(di-n-propylamino)tetralin discriminates between subtypes of the $5-\mathrm{HT}_{1}$ recognition site. Eur. J. Pharmacol. 90: 151-153.

Nelson, D. L., A. Herbet, S. Bourgoin, J. Glowinski, and M. Hamon (1978) Characteristics of central 5-HT receptors and their adaptive changes following intracerebral 5,7-dihydroxytryptamine administration in the rat. Mol. Pharmacol. 14: 983-995.

Nelson, D. L., N. W. Pedigo, and H. I. Yamamura (1980) Multiple types of serotonin receptors. In Psychopharmacology and Biochemistry of Neurotransmitter Receptors, H. I. Yamamura, R. W. Olsen, and E. Udsin, cds., pp. 325-338, Elsevier-North Holland, Amsterdam.

Paxinos, G., and C. Watson (1982) The Rat Brain in Stereotaxic Coordinates. Academic, New York.

Pazos, A., and J. M. Palacios (1985) Quantitative autoradiographic mapping of serotonin receptors in the rat brain. I-Serotonin-1 receptors. Brain Res. 346: 205-230.

Pazos, A., C. Cortès, and J. M. Palacios (1984a) Quantitative receptor autoradiography: Application to the characterization of multiple receptor subtypes. J. Receptor Res. 4: 645-656.

Pazos, A., D. Hoyer, and J. M. Palacios (1984b) The binding of serotoninergic ligands to the porcine choroid plexus: Characterization of a new type of serotonin recognition site. Eur. J. Pharmacol. 106: 539546.

Pcdigo, N. W., H. I. Yamamura, and D. L. Nelson (1981) Discrimination of multiple $\left({ }^{3} \mathrm{H}\right) 5$-hydroxytryptamine binding sites by the neuroleptic spiperone in rat brain. J. Neurochem. 36: 220-226.

Peroutka, S. J., and S. H. Snyder (1979) Multiple serotonin receptors: Differential binding of $\left({ }^{3} \mathrm{H}\right) 5$-hydroxytryptamine, $\left({ }^{3} \mathrm{H}\right)$ lysergic acid diethylamide and $\left({ }^{3} \mathrm{H}\right)$ spiroperidol. Mol. Pharmacol. 16: 687-699.

Rainbow, T. C., W. V. Bleish, A. Biegon, and B. S. McEwen (1982) Quantitative densitometry of neurotransmitter receptors. J. Neurosci. Methods 5:127-138.

Rainbow, T. C., A. Biegon, and D. J. Berck (1984) Quantitative receptor autoradiography with tritium-labeled ligands: Comparison of biochemical and densitometric measurements. J. Neurosci. Methods 11: 231-241.

Shenker, A., S. Maayani, H. Weinstein, and J. P. Green (1985) Two 5-HT receptors linked to adenylate cyclase in guinea pig hippocampus are discriminated by 5-carboxamidotryptamine and spiperone. Eur. J. Pharmacol. 109: 427-429.

Sills, M. A., B. B. Wolfe, and A. Frazer (1984) Determination of selective and non-selective compounds of the $5-\mathrm{HT}_{1 \mathrm{~A}}$ and $5-\mathrm{HT}_{\mathrm{t}}$ receptor subtypes in rat frontal cortex. J. Pharmacol. Exp. Ther. 231 : $480-487$.

Sprouse, J. S., and G. K. Aghajanian (1985) Serotonergic dorsal raphe neurons: Electrophysiological responses in rats to $5-\mathrm{HT}_{1 \mathrm{~A}}$ and $5-\mathrm{HT}_{1 \mathrm{R}}$ receptor subtype ligands. Soc. Neurosci. Abstr. 11: 47 (18.19).

Tricklebank, M. D., C. Forler, and J. R. Fozard (1985) The involvement of subtypes of the 5-HT, receptor and of catecholaminergic systems in the behavioural response to 8-hydroxy-2-(di-n-propylamino)tetralin in the rat. Eur. J. Pharmacol. 106: 271-282.

Trimble, M. R., and E. Zarifian (1984) Psychopharmacology of the Limbic System, Oxford U.P., Oxford, U.K.

Vergé, D., G. Daval, A. Patay, H. Gozlan, S. El Mestikawy, and M. Hamon (1985) Presynaptic 5-HT autoreceptors on serotoninergic cell bodies and/or dendrites but not terminals are of the $5-\mathrm{HT}_{1 \mathrm{~A}}$ subtype. Eur. J. Pharmacol. 113: 463-464.

Wamsley, J. K., M. A. Zarbin, W. S. Young, III, and M. J. Kuhar (1982) Distribution of opiate receptors in the monkey brain: An autoradiographic study. Neuroscience 7: 595-613. 